\title{
The Implementation Of Mawah Custom Process To Improve The Community Economy In Kuta Baro Subdistrict Aceh Besar
}

\author{
Nelly $^{1}$, Rahmi $^{2}$, Mahdani $^{3}$, Djuraidin Ismail ${ }^{4}$ \\ \{Nelly@serambimekkah.ac.id ${ }^{1}$, rahmi@ serambimekkah.ac.id ${ }^{2}$, \\ bungdani@yahoo.com ${ }^{3}$,djuraidin_ismail@yahoo.com ${ }^{4}$ \} \\ 1), 2) Lecturers of Management Studies Program Faculty of Economics, Serambi Mekkah University \\ 3) 4) Lecturers of Management Studies Program Faculty of Economics and Business,Syiah Kuala \\ University
}

\begin{abstract}
Mawah customary practice is very popular in Aceh so that with the customary practice of this Mawah much help the lives of the poor. This study aims Birthing a model implementation mawah customary practice in the district of KutaBaro, Aceh Besar district. And Generate a poverty reduction strategy based on local wisdom through customary practices mawahKutaBaro Sub-district, Aceh Besar District. Poverty is a key issue in Indonesia's development and economic quality is the key to the problem. The main problem in alleviating poverty in Indonesia today is related to the fact that economic growth is not spread evenly throughout Indonesia, as evidenced by the high income disparity between regions. The potential in the agricultural sector is very large, but most of the many farmers are among the poor and it is very ironic in Indonesia. The practice of indigenous mawah in KecamatanKutaBaro has been going on for generations, the practice that the community is doing is paddy fields, where the owners of the rice fields entrust their fields to be cultivated by the people who need the rice fields to help meet their daily needs where this practice can be one strategies for poverty alleviation in KutaBaro Aceh Besar sub-district. This study aims to give birth to a pattern of empowerment of traditional values mawah as a model of poverty alleviation. The location of this research is in KutaBaro sub-district, Aceh Besar district, with population in 5 (five) mukim areas. The number of samples is 5 (five) villages representing each mukim. The model for the implementation of customary practices that can be applied in KutaBaro sub-district is to make oral agreements based on trust. This has been done for generations. Collected data processing will be processed with the "Triangulation" approach. This research uses data collecting technique of interview, observation and documentation. From the research results can be seen that poverty alleviation can be done by the community itself by empowering the values of adatmawah that has long been practiced in Kecamtan Kuta Baro.
\end{abstract}

Keywords: Implementation of Mawah, Economic improvement.

\section{Introduction}

Poverty reduction is the central issue in development in Indonesia and the economic quality becomes a key issue. Agricultural development in Indonesia is still considered the most important of the overall economic development, especially since the agricultural sector 
has become the savior for the national economy because it increases their growth, while negative growth in other sector. Indonesia is known as an agrarian country where more than half of the population depends its livelihood on the agricultural sector, as the agricultural sector has been able to contribute to the livelihood of the Indonesian people and it is important in economic growth. In addition, the agricultural sector has also become a factor triggering the national economic growth, therefore, the agricultural sector until now still plays a role in the development of national economy [1]. Farm land especially rice field is one of the planting place for the majority of Indonesian population who live in rural areas. Commodity of paddy is one of the commodities of cultivation. Rice is closely related to the needs of the people and can be used as a mean for survival. The increasing number of people causes the need for rice is Increasing [2]. Agricultural development is inseparable from the development of rural areas and agriculture as the prime mover puts the economy. Land, labor potential, and the local economic base of rural agricultural development becomes a major factor. Currently recognized that agricultural development is not just resting in the village but also required the integration of the region and support facilities and infrastructure that is not only in the countryside. The economic structure of the region is the basic factor that differentiates one region to another, the difference is very closely related to the condition and potential of an area in terms of the physical environment, socio-economic and institutional.

KutaBaro District consists of the villages one of which can be said to have the potential for very rich natural resources which the territory has an area of $6107 \mathrm{Ha}$. Of the area is largely directed at the development potential of rural agricultural development is more focused on food production. In terms of natural resource potential villages in the district of KutaBaro has good prospects as a producer of rice production is promising. The phenomenon of limitations and their ownership status of agricultural land led to the emergence of various forms of cooperative relationships within the farming community. Generally, the relationship between the owner of the land to smallholders tural can be used as assets to be pledged their future.

Practice for this result (mawah) has been done in Aceh since the 16th century, this practice continued until. Mawah custom is very popular in Aceh so that with the customary practice of this Mawah much help the lives of the poor. With customary practice Mawah has a significant role in economic activity, the availability of grain is enough, terbantunya economy of the poor, to create jobs, people who have land can be explored, and the rise in productivity of rice and grain so there is no more land and rice displaced.

The concept for the results according to Mohammed (2000: 129), occurs when the owners of capital (sahibul mall) to surrender their capital to the manager (mudharib) being managed or operated, while the profits are divided according to the collective agreement.

Farm-based farming management is also known in Indonesian culture with various titles such as maro(1: 1) and mertelu(1:2) in Central Java, Nengah (1: 1) and Jejuron (1: 2) in Priangan, other names. In general, the agricultural production sharing agreement in Indonesia is regulated in Law no. 2 Year 1960. This Agreement was issued under the provisions of customary law in Indonesia and was motivated by the inability or absence of opportunity for the landowners to cultivate their own land, and the absence or lack of land owned by the tiller farmers and the willingness of farmers to obtain additional cultivation.

According to [3] management of farming with the pattern of revenue-sharing need to be preserved because it is inline with the principles of sharia (muzara'ah, mukhabarah, andmusaqah). Inaddition, various studies mention this system has been able to increase productivity and income farmers in justice. However, there are several things that need to be improved from the management of the farming system, especially regarding the assertion of rights and obligations of landowners and smallholders who need to be explained in agreement in writing, reporting to local government (Head of Sub-district), and announcement by the Village Head. It is also contained in Law no. 2 of 1960 as the 
objective of the issuance of the Revenue Sharing Law to provide legal certainty to the tiller farmers and to assert the right sandobligati on sfor the farmers and the land owners.

Cultivation of agricultural land with the profit sharing concept has been implemented since the first even been passed down from generation to generation until today. There are several concepts mawah carried out on the order of district community life of KutaBaro, Aceh Besar is: Mawah fields, Mawah ground (mawahTanoh), Mawah gardens, livestock and Mawah.

The formulation of the problem in this study is how to empower the customary practice of mawah in KutaBaro Aceh, Aceh Besar. While the purpose of this study is to give birth to a pattern of empowerment of the implementation of customary practice of mawah in KutaBaro, Aceh Besar.

\section{Metode Penelitian}

\subsection{Technique of Data Collection}

This study uses two types of data namely primary data and secondary data. Primary data was obtained by conducting direct interviews with 4 farmland owners, 5 farmers, 3 community leaders, namely village head, tuhapeut (village supervisor), and sub-district head as the head of government of KotaBaro, Aceh Besar. It also uses questionnaires to obtain data in quantitative form. Secondary data is obtained through the documentation available at the village and sub-district government office, such as the size of the area, the number of farmers, the area of agricultural land and so on, which is related to the research object.

\subsection{Data Analysis}

The method of data analysis used in this study is qualitative techniques that emphasize more on the analysis of inductive inference process and on the analysis of the dynamics of relationships between observed phenomena by holding scientific logic, and the emphasis is on an effort to answer research questions through formal ways of thinking and argumentative. The data collected through interviews, observations and seminars will be processed with qualitative descriptive approaches, aiming to describe the categories relevant to the objectives to be achieved in the study, thus giving birth to the perfect research output as the research aimed to achieve. To analyse the data qualitatively, the researcher pursues several techniques which are: (1) to observe the social phenomenon in the research location, (2) to identify problems by checking the interview data and answer the questionnaire, (3) to categorize the information obtained, 4). To trace and explain categorization, (5) to describe categorization relationships, (6) to draw general conclusions.

\section{Results And Discussion}

\subsection{Geographical Situation of Research Sites}

Kota Baro is one of the sub-districts located in Aceh Besar district of Aceh province, Indonesia. The area of Aceh Besar is located on the line 5,050 - 5,750 North Latitude and 94.990 - 95.930 East Longitude. The area of Aceh Besar is 2,903.50 km2, most of which is on land, and a small part of the archipelago. Approximately $10 \%$ of villages in Aceh Besar District are coastal villages, Aceh Besar District consists of 23 Sub-districts, 68 Residences and 604 villages. Kota Baro sub-district consists of 5 Residences with $61,07 \mathrm{~km}^{2}(6,107 \mathrm{Ha})$ 
sub-districts consisting of 47 villages, namely BuengCala with 10 villages, Leupung with 9 villages, Lamblang with 9 villages, Ateuk with villages 10, and Lamrabo there are 10 villages. and a small part of the archipelago. About $10 \%$ of villages in Aceh Besar District are coastal villages.

Table 2. Area of sub-district according to villages and type of land use in Kota Baro Subdistrict, 2018.

\begin{tabular}{|c|c|c|c|c|c|}
\hline \multirow[t]{2}{*}{ No } & \multirow[t]{2}{*}{ NamaGampong } & \multicolumn{4}{|c|}{ JenisPenggunaan } \\
\hline & & LahanSawah & LahanBukanSawah & $\begin{array}{c}\text { Lahan Non } \\
\text { Pertanian }\end{array}$ & LuasGampong \\
\hline 1 & Gue & 28 & 0 & 14 & 42 \\
\hline 2 & BabahJurong & 43 & 0 & 43 & 86 \\
\hline 3 & LambroDeyah & 14 & 0 & 13 & 27 \\
\hline 4 & Lam Baed & 34 & 0 & 42 & 76 \\
\hline 5 & KruengAnoi & 13 & 0 & 34 & 47 \\
\hline 6 & Cot Masam & 22 & 7 & 8 & 37 \\
\hline 7 & Cot Mancang & 81 & 15 & 45 & 141 \\
\hline 8 & BuengBakjok & 69 & 27 & 64 & 160 \\
\hline 9 & Cot Beut & 158 & 78 & 162 & 398 \\
\hline 10 & UjongBlang & 129 & 73 & 240 & 442 \\
\hline 11 & Seupeu & 16 & 0 & 33 & 49 \\
\hline 12 & Lam Neuheun & 34 & 0 & 35 & 69 \\
\hline 13 & Lam Puuk & 7 & 0 & 16 & 23 \\
\hline 14 & LambroeBileu & 10 & 0 & 16 & 26 \\
\hline 15 & LampohKeude & 0 & 0 & 44 & 44 \\
\hline 16 & Cot Peutano & 20 & 0 & 25 & 45 \\
\hline 17 & Cot Cut & 111 & 0 & 57 & 168 \\
\hline 18 & Lam Glumpang & 7 & 0 & 14 & 21 \\
\hline 19 & MeunasahBakTrieng & 22 & 0 & 12 & 34 \\
\hline 20 & Lam Asan & 5 & 0 & 9 & 14 \\
\hline 21 & Lamceu & 36 & 0 & 47 & 83 \\
\hline 22 & Cot Preh & 105 & 38 & 250 & 393 \\
\hline 23 & Puuk & 180 & 3 & 576 & 759 \\
\hline 24 & Lam Seunong & 98 & 7 & 9 & 114 \\
\hline 25 & Lam Trieng & 71 & 5 & 12 & 88 \\
\hline 26 & Beurangong & 17 & 0 & 22 & 39 \\
\hline 27 & Rabue & 148 & 0 & 27 & 175 \\
\hline 28 & Deyah & 90 & 0 & 28 & 118 \\
\hline 29 & Cucum & 27 & 0 & 24 & 51 \\
\hline 30 & Cot Yang & 22 & 0 & 15 & 37 \\
\hline 31 & Cot Raya & 21 & 0 & 23 & 44 \\
\hline 32 & LampohTarom & 5 & 0 & 9 & 14 \\
\hline 33 & Aron & 33 & 3 & 2 & 38 \\
\hline 34 & Lam Roh & 16 & 1 & 3 & 20 \\
\hline 35 & BakBuloh & 3 & 0 & 11 & 14 \\
\hline 36 & Lam Raya & 69 & 0 & 447 & 516 \\
\hline 37 & TumpokLampoh & 7 & 0 & 11 & 18 \\
\hline 38 & LambunotTanoh & 44 & 7 & 318 & 369 \\
\hline 39 & LambunotPaya & 84 & 0 & 325 & 409 \\
\hline 40 & Lamteube Mon Ara & 22 & 2 & 6 & 30 \\
\hline 41 & LamteubeGeupula & 5 & 0 & 8 & 13 \\
\hline 42 & Lam Alu Cut & 23 & 1 & 31 & 55 \\
\hline
\end{tabular}




\begin{tabular}{llcccc}
\hline No & NamaGampong & LahanSawah & $\begin{array}{c}\text { JenisPenggunaan } \\
\text { LahanBukanSawah }\end{array}$ & $\begin{array}{c}\text { Lahan Non } \\
\text { Pertanian }\end{array}$ & LuasGampong \\
\hline 43 & Lam Sabang & 21 & 0 & 9 & 30 \\
44 & Lam Alue Raya & 22 & 0 & 9 & 31 \\
45 & LeupungUleeAlue & 15 & 0 & 8 & 23 \\
46 & LeupungMesjid & 94 & 4 & 9 & 107 \\
47 & Cot Lamme & 98 & 29 & 443 & 570 \\
& & & & $3.608 \mathrm{Ha}$ & $6.107 \mathrm{Ha}$ \\
\hline
\end{tabular}

Source : Master File Of KutaBaro Sub-district Offoce,2018.

\subsection{Empowerment of customary values}

The implementation of customary mawah practices in KutaBaroSubdistrict has been going on for generations. The practice that the community is doing is downing the rice fields. Where paddy owners entrust their fields to be cultivated by people who need rice fields to help with their daily needs. In KutaBaroSubdistrict there is a vast expanse of rice fields, where the results of the KutaBaro District rice field are known for their excellent quality, therefore the term for cultivating rice fields. And this is where the practice of mawah custom has been handed down from generation to generation carried out by the community in KutaBaro District, Aceh Besar District. Mawah customary values empowerment can help the poor in KutaBaro sub-district. Mawah which is based on mutual trust between one another and followed by traditional values that have been going on from generation to generation until now. This customary practice is carried out in accordance with the traditional values prevailing in the district of KutaBaro. Such as the time set for going down the fields or abstinence from rice fields and so on.

\subsection{Model implementation of customary practice mawah}

The model for the implementation of customary practices that can be applied in KutaBaro sub-district is to make oral agreements based on trust. This has been done for generations. The results of interviews and observations of researchers in the field explained that there had never been a dispute or conflict as long as this customary practice was implemented.

\subsection{The Mawah process run by the community of KutaBaro sub-district is}

1. Starting from an oral agreement between farmer and rice field owner, when the first time the owner of a rice field gives the farmer the opportunity to work on his rice field. This agreement is based on trust, there is no written agreement. The community is accustomed to customs that exist from generation to generation. The trust given is the main capital. If the trust is not in accordance with the agreement, then generally the owner of the rice field will divert the other farmers.

2. The rice planting season begins two months after the harvest. In general, people in KutaBaro sub-district during the 2 months before the rice planting started, they released livestock into the rice fields with the aim of utilizing the remains of rice plants for livestock. The term used by the local community is "bukainerok" or "MusangluahBlang".

3.There are two rice planting seasons, namely "padee thon" (rainy season) is the rainy season and "Padee P" or "PadeeRueung" (Gadu Season) is the dry season. At that time all the cattle were caged. Padeethon (rainy season) is rice planted in the rainy season. In general, in KutaBaroSubdistrict sowing the seeds(taboo bijeh)is startedin November. Whereas Padee P or PadeeRueung (Gadu season) is held in May. 
4. In the season of Padee Thon (rainy season) usually the yields obtained are higher than in the Padee $P$ season or the Gadu season because of the Padee Thon season, besides the availability of irrigation water, it is also helped by rainwater, while Padee $P$ only relies on available irrigation water, if the rice fields which is close to technical irrigation, so the rice is always in good condition, and for the rice field which is far from irrigation during the Padee P season, it mostly fails to harvest and is sold for animal feed (cattle).

5.During the planting season, many smallholders receive tithe of income from the rice fields they cultivate. It depends on the size of the cultivated rice field, which is measured by using the term Gunca, 1 gunca = 16 Blet / tem (coffee can or can of 25 kilo paint) or a measure of $180 \mathrm{~kg}$ of rice, the tithe obtained from income is 6 or more than $1080 \mathrm{~kg}$ of rice. In the past, people used the "kateng". The size of 1 kateng $=20$ bamboos and 1 nalehof rice $=16$ bamboo. 8 kateng = 1 gunca,10naleh = 1 gunca , which is made from bambo or rattan. But farmers in KutaBaro sub-district do not use kateng anymore. They use blet / tem.

6. Revenue sharing rules have been carried out from generation to generation.If the location of the rice fields is close to the place of residence and irrigation $\mathrm{s}$, the sharing system is divided into 1: 3 . And if it is far from irrigation and residence, then 1: 4. The technique: the size of the farmer in measuring the results is in blet (10 bamboo) and filled in a sack with $36 \mathrm{~kg}$ of rice to calculate the revenue sharing.For the sharing of 1: 3 , it means that for 3 smallholder and 1 for the owner.

7.There is one custom from KutaBaro sub-district that has never been forgot, namely kenduriblang (a ritual meal which is carried out in the rice filed), which is carried out when the age of rice is 1 month and a half. There is a custom that is not to be violated which is a prohibition for all farmers; after 3 days of the ritual meal, it is not allowed to go to rice fields. if anyone breaks the customs, it will be faced with customary sanctions. In some villages in KutaBaro sub-district the sanction is a fine of one goat or cow. This is very concerned because beliefs or customs that have been run for generations are aimed to avoid any kinds of diseases.

In KutaBaroSubdistrict, mawahis one of the community's activities in overcoming poverty. Because through mawah, it can help the economy of the community.

\section{Conclusions}

1. Model implementation of customary practices that can be applied in KutaBaro sub-district is by making an oral agreement based on trust. This has been done for generations. The results of interviews and observations of researchers in the field explained that there had never been a dispute or conflict as long as this customary practice was implemented.

2. Mawahcustomary empowerment can help poor people in KutaBaro sub-district. Mawah which is based on mutual trust between one another and followed by traditional values that have been going on from generation to generation until now. This customary practice is carried out in accordance with the traditional values prevailing in the district of KutaBaro. Such as the time set for going down the fields or abstinence from rice fields and so on. 


\section{Suggestion}

1. It is suggested to the people of Aceh, especially to the KutaBaro District community to promote and continue to maintain the practice of Mawah customary in KutaBaro District because it is very useful for the community in alleviating poverty.

2. It is recommended to the government to help the community, especially the farming community to provide capital for the Mawah actors, because the Acehnese traditional customs are charged to the manager.

3. It is recommended to the Aceh House of Representatives (DPRA) to produce a Qanun related to Mawah which has not been available so far, so that it can become a guideline for the Mawah community, as well as for judges in the Aceh Sharia court. It is recommended to the government to help the community, especially the farming community to provide capital for the Mawah actors, because the Acehnese traditional customs are charged to the manager.

4. It is recommended to the Aceh House of Representatives (DPRA) to give birth to Qanun relating to Mawah which so far does not yet exist, so that it can become a guideline for the Mawah community, as well as for judges in the Aceh Sharia Court to resolve disputes in the case of the Mawah case.

\section{References}

[1] E. A. Pane, "Sistem Bagi Hasil Dan Pendapatan Petani Padi Di Kabupaten Seluma Provinsi Bengkulu," Program Studi Agribisnis Jurusan Sosial Ekonomi Pertanian Fakultas Pertanian Universitas Bengkulu, 2014.

[2] A. Nurhayati, W. Lili, H. Titin, and I. Riyantini, "Derivatif Analysis of Economic and Social Aspect of Added Value Minapadi (Paddy-Fish Integrative Farming) a Case Study in the Village of Sagaracipta Ciparay Sub District, Bandung West Java Province, Indonesia," Aquat. Procedia 7, pp. $12-18,2015$.

[3] S. Abdullah, "Sistem Bagi Hasil dalam Sektor Pertanian," Islam. Agri-Economist Forum, 2014.

[4] Abdurrahman. (2014). Praktek mawah melalui mudharabah dalam masyarakat Aceh, Banda Aceh: UIN Ar-Ranniry

[5] Damanhur dan Muammar Khaddafi, 2013.Konsep Mawah dalam Meningkatkan Kesejahteraan Masyarakat di Kabupaten Aceh Utara, Journal Economic Management dan Bussiness, Vol. 14 No. 4 Tahun 2013.

[6] Dressler, W., Koning, J de., Montefrio, M., and Firn, J. (2016). Land sharing not sparing in the "green economy": The role of livelihood bricolage in conservation and development in the Philippines.Geoforum , 76, 75-89. journal homepage: www.elsevier.com/locate/geoforum.

[7] Durand, C ., and Fournier, S. (2017). Can Geographical Indications Modernize Indonesian an Vietnamese Agriculture? Analyzing the Role of National andLocal Governments and Producers' Strategies.World Development, 98, 93-104. www.elsevier.com/locate/worlddev.

[8] Edi Marsudi. 2011. Identifikasi Sistem Kerjasama Petani dan Penggarap dan Pemilik Tanah dalam Kaitannya dengan Pemerataan Pendapatan Petani Sawah Beririgasi (Studi Terhadap Kelembagaan Petani pada Wilayah Jaringan Sekunder Irigasai Daya Daboh dan Lamcot Kabupaten Aceh Besar). Jurnal Agrisep, Vol. 12 No. 12011.

[9] Iko, H. (2008). Pelaksanaan Perjanjian Bagi Hasil Tanah Pertanian Di Kecamatan Bulakamba Kabupaten Brebes Jawa Tengah. (Tesis, tidak dipublikasi).Program Pascasarjana Fakultas Hukum Universitas Diponegoro Semarang. 
[10] Koirala, K. H., Mishra, A., and Mohanty, S. (2016). Impact of land ownership on productivity and efficiency of ricefarmers: The case of the Philippines. Land Use Policy, 50, 371-378. journal home page: www.elsevier.com/locate/landusepol.

[11] Marsudi, E. (2011). The Identification of Cooperation System between Farmer and Land Owner In Creating an Even Income Distribution of Irrigated Rice Field Farmers (A Study toward the Institutional of Farmers in Secondary Network of Irrigation in Dayah Daboh and Lamcot in District of Aceh Besar). Agrisep, 12, (1), 1-6.

[12] Nurmadany, R. (2016).Pelaksanaan Perjanjian Bagi Hasil Tanah Pertanian Antara Pemilik Tanah dan Penggarap di Kabupaten Sleman. Journal Universitas Atmajaya, 1-12. Fakultas Hukum Universitas Atmajaya Yogyakarta.

[13] Poole, M., and Jenkins, G. (2013). The Impact of Economic Democracy: Profit-sharing and Employee-Shareholding Schemes, Routledge.Contoh gratis Rp559.358 Beli Rp447.48

[14] Purnami, Tri. (2012).Pelaksanaan Bagi Hasil Tanah Pertanian (Studi Komparatif UndangUndang No.2 Tahun 1960 Tentang Perjanjian BagiHasil Tanah Pertanian dengan Pelaksanaan Bagi Hasil di Desa Blagungan Kecamatan Kalijambe Kabupaten Sragen). Naskah Publoikasi, Fakultas Keguruan Dan Ilmu Pendidikan Universitas Muhammadiyah Surakarta.

[15] Sibarani, Robert. 2012.

PendekatanAntropolinguistikDalamMenggaliKearifanLokalSebagaiIdentitasBangsa. ProsidingThe $5^{\text {th }}$ International Conference on Indonesian Studies: "Ethnicity and Globalization". Medan: Universitas Sumatera Utara

[16] Strochlic, R., and Hamerschlag, K. (2005).Best Labor Management Practices on Twelve California Farms: Toward a More Sustainable Food System. California Institute for Rural Studies, pp.1-28. 